\title{
Retraction Note: Gene-gene interaction network analysis of ovarian cancer using TCGA data
}

\author{
Huanchun Ying ${ }^{1 *}$, Jing Lv², Tianshu Ying ${ }^{1}$, Shanshan Jin ${ }^{1}$, Jingru Shao ${ }^{1}$, Lili Wang ${ }^{1}$, Hongying $\mathrm{Xu}^{3}$, Bin Yuan ${ }^{2}$ \\ and Qing Yang ${ }^{1}$
}

\section{Retraction}

The Publisher and Editor regretfully retract this article [1] because the peer-review process was inappropriately influenced and compromised. As a result, the scientific integrity of the article cannot be guaranteed. A systematic and detailed investigation suggests that a third party was involved in supplying fabricated details of potential peer reviewers for a large number of manuscripts submitted to different journals. In accordance with recommendations from COPE we have retracted all affected published articles, including this one. It was not possible to determine beyond doubt that the authors of this particular article were aware of any third party attempts to manipulate peer review of their manuscript.

\section{Update posted (11 ${ }^{\text {th }}$ April, 2016)}

BioMed Central has been informed by the authors' institution that it has conducted an investigation that found that the authors of this article [1] authorized third-parties to submit the manuscript on their behalf, but did not sufficiently supervise or manage the submission process. The investigation concluded that this behavior constituted academic misconduct.

\section{Author details \\ ${ }^{1}$ Department of Gynecology and Obstetrics, Shengjing Hospital of China Medical University, No.36, Sanhao Street, Heping District, Shenyang, Liaoning Province 110004, China. ${ }^{2}$ Department of Oncology, The fifth Hospital of Shenyang, Shenyang 110023, China. ${ }^{3}$ Department of Gynecology and Obstetrics, The ninth Hospital of Shenyang, Shenyang 110024, China.}

Received: 26 January 2015 Accepted: 27 February 2015 Published online: 26 March 2015

\section{References}

1. Ying $H$, Lv J, Ying T, Jin S, Shao J, Wang L, et al. Gene-gene interaction network analysis of ovarian cancer using TCGA data. J Ovarian Res. 2013;6:88.

* Correspondence: huanchunyiing@hotmail.com

'Department of Gynecology and Obstetrics, Shengjing Hospital of China Medical University, No.36, Sanhao Street, Heping District, Shenyang, Liaoning Province 110004, China

\section{Submit your next manuscript to BioMed Central and take full advantage of:}

- Convenient online submission

- Thorough peer review

- No space constraints or color figure charges

- Immediate publication on acceptance

- Inclusion in PubMed, CAS, Scopus and Google Scholar

- Research which is freely available for redistribution

Submit your manuscript at

www.biomedcentral.com/submit

C BioMed Central

\section{Biomed Central}

(c) 2015 Ying et al.; licensee BioMed Central. This is an Open Access article distributed under the terms of the Creative Commons Attribution License (http://creativecommons.org/licenses/by/4.0) which permits unrestricted use, distribution, and reproduction in any medium, provided the original work is properly credited. The Creative Commons Public Domain Dedication waiver (http://creativecommons.org/publicdomain/zero/1.0/) applies to the data made available in this article, unless otherwise stated. 